\title{
Aiming Toward a Political Pastoral Theology
}

\author{
Ryan LaMothe ${ }^{1}$
}

Published online: 3 December 2015

(C) Springer Science+Business Media New York 2015

I am writing this introduction the day after of hearing the sad news that Don Capps died. Don made numerous contributions to Pastoral Psychology, and he was a friend, mentor, and colleague of Lewis Rambo, Nathan Carlin, and myself. While his death is a terrible loss, I think we take solace in having known a man who was a compassionate and profoundly creative scholar who was also interested in his colleagues and students - their lives and their work.

But what does all of this grief have to do with this current issue? Some years ago, after reading one of my articles, Don wrote and told me of his interest in Malcolm X. Apparently they were born in the same city, but Don's interest had more to do with the courage Malcolm X displayed standing up to white racists. Whatever Don's intention was in telling me this, I took this as his blessing on the work I was doing in the area of politics, economics, and pastoral theology. I hasten to add to this memory that one of Don's doctoral students, Lewis Rambo, became editor of Pastoral Psychology and, like Don, Lewis actively supports the work of others. Indeed, in the last 15 years, Lewis has enthusiastically encouraged my work, and I am deeply grateful for that and our email conversations. More particularly, it was Lewis's idea to publish these articles as part of a special issue. When he asked me if I would be open to that (who would not?), I was gratified and humbled. Most of us toil away in solitude as we write, wondering if anyone reads our articles and books. It is a great boon to have someone of Don's and Lewis's stature recognize and encourage my work. I also deeply appreciate Nathan Carlin's introduction. Nathan reminds me of Don, both in terms of his generosity, humility, and compassion as well as his prodigious productivity. Every time I turn around he is publishing another book or article.

A final word: my interest in critically engaging political and economic systems and structures is fueled by urgency and hope that teeters on the brink of despair. When I was growing up, there was a collective anxiety about the possibility of nuclear war and the annihilation of the human species. To some degree this threat has receded, only to be replaced by the ever-growing reality of global warming and its dire consequences not only for humans but for other species. Both threats reveal the power of human creativity and industry as well as

Ryan LaMothe

rlamothe@saintmeinrad.edu

1 Saint Meinrad Seminary and School of Theology, 200 Hill Drive, St. Meinrad, IN 47577, USA 
of ignorance, stupidity, and greed - the stuff of tragedy. Added to this are my feelings of outrage over the years that the United States's continued imperial political and economic policies that have destabilized countries and, indeed, regions of the world. Outrage extends to our seemingly unquestioning embrace of neoliberal capitalism, which has led to staggering economic inequalities and poverty. Given this, it seems to me that pastoral theologians and caregivers must face the political and economic realities that are implicated in the slide toward the sixth extinction, U.S. imperialism, and the sacralization of capitalism. When I think of my urgency, it is not for my own life. I live quite comfortably and I will long be dead when the brunt of global warming and concomitant disasters emerge. Urgency is for future generations of human beings and for our brothers and sisters in the ocean, on land, and of the air. Write, organize, protest. 